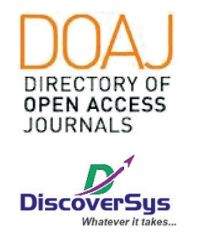

Published by DiscoverSys

\section{Perbandingan Kadar NT-proBNP Serum Pasien PGK eGFR $<60$ Pre- Dialisis dengan dan tanpa Gagal Jantung di RSUD DR Soetomo Surabaya}

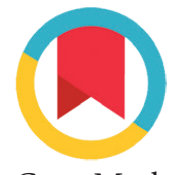

CrossMark

\author{
Made Padma Puspita, ${ }^{1}$ Widodo, ${ }^{2}$ Agus Subagjo ${ }^{3}$
}

\section{ABSTRACT}

Background: N-terminal-proBNP (NT-proBNP) is one of the most important biomarkers in diagnosing heart failure (HF). The excretion of NT-proBNP is affected by the decline of kidney function, thus the interpretation of serum levels of NT-proBNP in chronic kidney disease (CKD) patients to diagnose HF needs to be assessed carefully. Therefore, the purpose of this study is to investigated the difference between NTproBNP levels in CKD patient with and without heart failure.

Method: This observational analytic with cross-sectional study examined primary data of the serum level of NT-proBNP in predialyzed CKD patients with and without HF in outpatient clinic in Dr. Soetomo hospital, Surabaya between August and September 2018. Kidney function in predialyzed patients were classified into five stages using the Cockcroft Gault formula of estimated glomerular filtration rate
(eGFR). Patients with eGFR $<60 \mathrm{~mL} / \mathrm{min} / 1.73 \mathrm{~m}^{2}$ were included in this study. The differences between NT-proBNP levels in predialyzed CKD patients with and without heart failure were then analyzed using univariate and bivariate analysis.

Results: The study population consisted of 50 predialyzed CKD patients which include 25 patients with $\mathrm{HF}$ and 25 patients without $\mathrm{HF}$. The NT-proBNP mean in HF patients was $[23,082 \mathrm{pg} / \mathrm{mL}(22,413)]$ and in patients without HF was [815 pg/mL (651)]. There was significant difference in NT-proBNP level between patients with $\mathrm{HF}$ and without $H F(p<0,001)$.

Conclusion: This study showed that there was significant increase in NT-proBNP level of predialyzed CKD patients with HF compare to patients without $\mathrm{HF}$.
${ }^{1}$ Residen IImu Penyakit Dalam, Fakultas Kedokteran Universitas Airlangga, Surabaya

${ }^{2}$ Divisi Ginjal Hipertensi, Departemen Ilmu Penyakit Dalam, Fakultas Kedokteran Universitas Airlangga, Surabaya

${ }^{3}$ Departemen Kardiologi, Fakultas Kedokteran Universitas Airlangga, Surabaya

${ }^{*}$ Correspondence to:
Keywords: NT proBNP, kidney failure, Heart failure

Cite This Article: Puspita, M.P., Widodo, Subagjo, A. 2019. Perbandingan Kadar NT-proBNP Serum Pasien PGK eGFR <60 Pre- Dialisis dengan dan tanpa Gagal Jantung di RSUD DR Soetomo Surabaya. Intisari Sains Medis 10(3): 693-697. D0I: 10.15562/ism.v10i3.382

\section{ABSTRAK}

Latar Belakang: N-terminal-proBNP (NT-proBNP) merupakan salah satu penanda biologis yang berguna dalam mendiagnosis gagal jantung dimana ekskresi NT-proBNP dipengaruhi oleh penurunan fungsi ginjal sehingga penggunaan NT-proBNP untuk mendiagnosis gagal jantung pada pasien dengan penyakit ginjal kronis (PGK) perlu diinterpretasikan secara hati-hati. Penelitian ini bertujuan untuk menentukan apakah terdapat perbedaan antara kadar NT-proBNP pada pasien dengan PGK non dialisis dengan dan tanpa gagal jantung. Metode: Pada penelitian observasi analisis potong lintang ini, digunakan data primer kadar serum NT-proBNP pada pasien PGK predialisis baik yang mengalami gagal jantung maupun tidak di poliklinik RS dr. Soetomo, Surabaya periode Agustus hingga September 2018. Pasien kemudian dikelompokan menjadi 5 kelompok berdasarkan eGFR yang dihitung menggunakan formula Cockcroft
Gault. Pasien dengan eGFR $<60 \mathrm{~mL} / \mathrm{min} / 1,73 \mathrm{~m}^{2}$ dimasukan kedalam penelitian. Perbedaan kadar NT-proBNP pada pasien PGK predialisis dengan atau tanpa gagal jantung kemudian dianalisis menggunakan analisis univariat dan bivarat.

Hasil: Pada penelitian ini, didapatkan sampel 50 pasien PGK predialisis dimana terdapat 25 pasien dengan gagal jantung dan 25 pasien tanpa gagal. Didapatkan rerata kadar NT-proBNP pada subjek gagal jantung sebesar [23.082 pg/mL (22.413)] dan tanpa gagal jantung sebesar $[815 \mathrm{pg} / \mathrm{mL}$ (651)]. Terdapat perbedaan kada NT-proBNP yang signifikan antara pasien PGK predialisis dengan dan tanpa gagal jantung $(p<0,001)$.

Kesimpulan: Pada penelitian ini didapatkan peningkatan kadar NT proBNP yang signifikan antara pasien PGK predialisis dengan gagal jantung dibandingkan pasien PGK predialisis tanpa gagal jantung

Kata kunci: NT-proBNP, penyakit ginjal kronis, gagal jantung

Cite Pasal Ini: Puspita, M.P., Widodo, Subagjo, A. 2019. Perbandingan Kadar NT-proBNP Serum Pasien PGK eGFR <60 Pre- Dialisis dengan dan tanpa Gagal Jantung di RSUD DR Soetomo Surabaya. Intisari Sains Medis 10(3): 693-697. DOI: 10.15562/ism.v10i3.382

\section{PENDAHULUAN}

Penyakit ginjal kronis (PGK) masih menjadi tantangan kesehatan global dan merupakan salah satu faktor risiko penting terjadinya penyakit kardiovaskuler termasuk gagal jantung, baik melalui jalur
Disetujui: $14-12-2018$

Diterbitkan: 01-12-2019 
tradisional (umur, hipertensi, diabetes, dislipidemia) maupun jalur non-tradisional (gangguan metabolisme mineral, inflamasi kronis, anemia, malnutrisi). ${ }^{1}$ Salah satu cara dalam membantu penegakkan diagnosis gagal jantung adalah dengan menggunakan $\mathrm{N}$ terminal-ProBrain Natriuretic Peptide (NT-proBNP) sebagai penanda biologis yang telah diterima secara luas. Namun beberapa penelitian menunjukan adanya gangguan ekskresi NT-proBNP pada pasien dengan PGK sehingga interpretasi NT- proBNP pada pasien dengan PGK harus dilakukan dengan hati-hati agar tidak terjadi over-diagnose maupun under-diagnose. ${ }^{2}$ Peningkatan NT-proBNP pada pasien PGK terjadi akibat adanya regangan dinding ventrikel pada kondisi hipervolemia, proses inflamasi kronis akibat rangsangan sistem renin-angiotensin-aldosteron (RAA), dan berkurangnya ekskresi NT-proBNP akibat gangguan fungsi ginjal secara langsung., ${ }^{1,3}$ Sehingga pengetahuan mengenai perbandingan rerata kadar NT-proBNP pada pasien PGK dengan gagal jantung dan tanpa gagal jantung menjadi

Tabel 1 Demografi dan Karakteristik Umum Subjek Penelitian

\begin{tabular}{|c|c|c|}
\hline Karakteristik & Rerata & $\mathrm{N}(\%)$ \\
\hline Umur (tahun) & 49 & \\
\hline \multicolumn{3}{|l|}{ Jenis kelamin } \\
\hline Laki-laki & & $36(72)$ \\
\hline Perempuan & & $14(28)$ \\
\hline Berat badan $(\mathrm{kg})$ & 62,7 & \\
\hline \multicolumn{3}{|l|}{ Tekanan darah } \\
\hline Sistolik (mmHg) & 145 & \\
\hline Diastolik (mmHg) & 82 & \\
\hline Anemia & & $23(45)$ \\
\hline Riwayat diabetes melitus & & $33(66)$ \\
\hline Riwayat hipertensi & & $27(54)$ \\
\hline Frekuensi nadi (kali/menit) & 93 & \\
\hline Frekuensi nafas (kali/menit) & 21 & \\
\hline Kadar C-reaktif protein $(\mathrm{mg} / \mathrm{L})$ & 25 & \\
\hline Estimasi LFG (ml/menit) & 25,4 & \\
\hline Kadar BUN (mg/dL) & 51,6 & \\
\hline Kadar SGOT $(\mu / \mathrm{L})$ & 33 & \\
\hline Kadar SGPT $(\mu / L)$ & 30 & \\
\hline Kadar albumin plasma (g/dL) & 3,5 & \\
\hline Kadar gula darah acak (mg/dL) & 114 & \\
\hline Kadar natrium serum $(\mathrm{mMol} / \mathrm{L})$ & 137 & \\
\hline Kadar kalium serum (mMol/L) & 4,3 & \\
\hline Kadar klorida serum (mMol/L) & 104 & \\
\hline Fraksi ejeksi (\%) & 52 & \\
\hline PCWP (mmHg) & 14 & \\
\hline
\end{tabular}

sangat penting dalam membantu klinisi menegakkan diagnosis gagal jantung.

\section{METODE}

Penelitian ini merupakan penelitian analitik obervasional dengan desain potong lintang. Penelitian ini dilakukan di Instalasi Rawat Jalan Poliklinik Ginjal dan Hipertensi RSUD Dr. Soetomo, Surabaya periode Agustus hingga September 2018. Besar sampel mínimum pada penelitian ini adalah 50 sampel dimana sampel tersebut dipilih menggunakan teknik konsekutif, yaitu semua pasien PGK dengan dan tanpa gagal jantung yang memenuhi kriteria inklusi dan eksklusi. Kriteria inklusi pada penelitian ini adalah semua pasien usia 21-60 tahun yang mengalami PGK dan belum pernah didialisis dengan eGFR $<60 \mathrm{ml} /$ menit $/ 1,73 \mathrm{~m}^{2}$ baik dengan gagal jantung maupun tanpa gagal jantung yang berobat di Instalasi Rawat Jalan Poliklinik Ginjal dan Hipertensi RSUD Dr.Soetomo, Surabaya dan bersedia menandatangani informed consent. Sedangkan kriteria ekslusi adalah pasien dengan sindrom coroner akut (SKA) dalam 6 bulan terakhir, pasien dengan penyakit paru obstruktif kronis (PPOK), obesitas, hipertiroid, sepsis, dan sirosis hati.

Sumber data dalam penelitian ini adalah berupa data primer pasien. Kadar NT-proBNP dibagi menjadi 3 kelompok, yakni kelompok dengan kadar NT-proBNP $<900$ pg/mL, 900-1200 pg/ $\mathrm{mL}$, dan $>1200 \mathrm{pg} / \mathrm{mL}$. Data kemudian diolah, disajikan dalam bentuk tabel serta dilakukan analisis hasil. Dilakukan analisis univariat untuk mendeskripsikan karakteristik responden dalam penelitian. Perbedaan kadar NT proBNP antar kelompok pasien PGK dengan gagal jantung dan pasien PGK tanpa gagal jantung akan dianalisis dengan analisis statistik 2 sample $t$-test atau alternatifnya dan dikatakan bermakna jika nilai $\mathrm{p}<0,05$. Data diolah dengan Statistical Product and Service Solution (SPSS) 23 for Windows.

\section{HASIL PENELITIAN}

Didapatkan jumlah sampel sebanyak 50 sampel yang terdiri dari masing-masing 25 pasien PGK dengan gagal jantung dan 25 pasien PGK tanpa gagal jantung. Berikut disajikan dalam Tabel 1, deskripsi sampel berdasarkan karakteristik usia, jenis kelamin, berat badan, tekanan darah, anemia, riwayat diabetes mellitus, riwayat hipertensi, frekuensi nadi, frekuensi nafas, kadar CRP, e-GFR, kadar BUN, kadar SGOT, kadar SGPT, kadar albumin, kadar gula darah acak, kadar natrium serum, kadar klorida serum, fraksi ejeksi dan PCWP. Pada 
Tabel 2 Karakteristik Subjek Penelitian dengan dan tanpa Diserta Gagal Jantung

\begin{tabular}{lcc}
\hline Parameter & $\begin{array}{c}\text { Subjek dengan gagal jantung } \\
(\mathbf{N}=\mathbf{2 5})\end{array}$ & $\begin{array}{c}\text { Subjek tanpa gagal jantung } \\
(\mathbf{N}=\mathbf{2 5})\end{array}$ \\
\hline Demografi & & $50 \pm 7$ \\
$\quad$ Umur (tahun), rerata \pm SB & $49 \pm 7$ & 16 \\
Jenis kelamin (n) & 21 & 10 \\
Laki-laki (n) & 4 & \\
Penyakit komorbid & & 15 \\
Hipertensi (n) & 15 & 12 \\
Terapi obat antihipertensi (n) & 12 & 15 \\
Diabetes mellitus (n) & 18 & 12 \\
Anemia & 15 & \\
Parameter ekokardiografi & & $60 \pm 5$ \\
Fraksi ejeksi $(\%)$, rerata \pm SB & $44 \pm 7$ & $12 \pm 3$ \\
PCWP (mmHg), rerata $\pm S B$ & $15 \pm 4$ & 7 \\
LVH (n) & 23 & 7 \\
Disfungsi diastolic (n) & 15 & \\
\hline
\end{tabular}

\begin{tabular}{|c|c|c|c|c|}
\hline Kadar NT-proBNP (pg/dL) & rerata \pm SB & $\begin{array}{l}\text { minimum- } \\
\text { maksimum }\end{array}$ & $\begin{array}{c}\text { Median } \\
\text { (interkuartil) }\end{array}$ & signifikansi \\
\hline Dengan gagal jantung & $23.082 \pm 22.413$ & $1.138-70.000$ & $\begin{array}{c}13.300 \\
(5.971-32.860)\end{array}$ & \\
\hline Tanpa gagal jantung & $815 \pm 651$ & $50-2.615$ & $\begin{array}{c}3.076,5 \\
(581,8-13.620)\end{array}$ & $\mathrm{P}<0,001$ \\
\hline Total sampel & $11.949 \pm 19.306$ & $50-70.000$ & $\begin{array}{c}589 \\
(403-1.019)\end{array}$ & \\
\hline
\end{tabular}

Tabel 2 disajikan data karakteristik umum pasien dengan dan tanpa gagal jantung.

Pada penelitian ini, didapatkan rerata kadar NT-proBNP pada subjek dengan gagal jantung adalah [23.082 pg/mL (22.413)] dan pada subjek tanpa gagal jantung adalah $[815 \mathrm{pg} / \mathrm{mL}$ (651)]. Pada seluruh subyek penelitian, dijumpai rentang kadar NT-ProBNP darah antara $50 \mathrm{pg} / \mathrm{mL}$ hingga $70.000 \mathrm{pg} / \mathrm{mL}$ dengan media $3.076,5 \mathrm{pg} /$ $\mathrm{mL}$. Pada kelompok gagal jantung $(\mathrm{n}=25)$, rerata kadar NT-ProBNP adalah [23.082 pg/mL (13.300)], sedangkan kelompok tanpa gagal jantung $(\mathrm{n}=25)$ memiliki rerata kadar NT-ProBNP adalah [815 pg/ $\mathrm{mL}$ (589)] sebagaimana yang disajikan dalam Tabel 3 .

Pada penelitian ini, didapatkan penyebaran data yang terdistribusi tidak normal dan tidak homogen, sehingga menggunakan uji beda non-parametrik Kolmogorov-Smirnov. Dari analisis data non-parametrik, dijumpai kadar NT-proBNP darah yang lebih tinggi pada subyek dengan gagal jantung dibandingkan tanpa disertai gagal jantung (mean rank 38 vs 13, p=0,001). Kemudian didapatkan hasil bahwa pada pasien PGK dengan gagal jantung, sebanyak $46 \%$ pasien memiliki kadar NT-proBNP $>1200$. Sedangkan pada pasien PGK tanpa gagal jantung, sebanyak $48 \%$ pasien memiliki kadar NT-proBNP $<900$ pg/mL.

\section{DISKUSI}

Persebaran sampel berdasarkan jenis kelamin menunjukkan jumlah sampel laki-laki lebih banyak dibandingkan perempuan yaitu dengan perbandingan 2,25:1. Hasil penelitian ini sejalan dengan hasil penelitian yang dilakukan oleh Park $\mathrm{dkk},{ }^{4}$ menunjukkan perbandingan sampel lakilaki dan perempuan 4,46:1. Diabetes mellitus menjadi faktor resiko terbanyak yang ditemukan pada pasien dengan PGK pada penelitian ini yaitu sebanyak 33 sampel (66\%). Terdapat ketidaksesuaian dengan penelitian yang dilakukan oleh Takase $\mathrm{dkk}^{5}$ dimana faktor resiko tertinggi PGK adalah hipertensi $(37,5 \%)$ kemudian diikuti oleh diabetes mellitus (19,5\%). 
Pada penelitian ini, didapatkan rerata eGFR sebesar $\left[25,4 \mathrm{ml} / \mathrm{menit} / 1,73 \mathrm{~m}^{2}(11,13)\right]$ sedangkan pada penelitian yang dilakukan oleh Takase $\mathrm{dkk}^{5}$ didapatkan rerata eGFR sebesar $[55,7 \mathrm{ml} /$ menit/1,73m $\left.{ }^{2}(26,1)\right]$. Perbedaan ini kemungkinan disebabkan karena adanya perbedaan subjek penelitian dimana pada penelitian yang dilakukan oleh Takase $\mathrm{dkk}^{5}$ menggunakan pasien PGK dengan dialisis rutin sedangkan pada penelitian ini menggunakan pasien PGK predialisis. Selain itu, data pada penelitian ini menunjukan peningkatan kadar NT-proBNP pada pasien PGK dengan gagal jantung dengan sampel terbanyak memiliki kadar NT-proBNP $>1.200 \mathrm{pg} / \mathrm{mL}$ sesuai dengan teori bahwa terjadi peningkatan NT-proBNP yang signifikan pada pasien dengan gagal jantung. ${ }^{6}$

Pada penelitian ini digunakan 25 sampel PGK dengan gagal jantung yang dibuktikan secara klinis dan melalui pemeriksaan dengan ekokardiografi. Dalam penelitian ini, dari 25 sampel PGK dengan gagal jantung, 23 sampel diantaranya mengalami hipertrofi ventrikel kiri. Selain itu, hipertrofi ventrikel kiri juga terjadi pada 7 sampel dari 25 sampel PGK tanpa gagal jantung. Hal ini sesuai dengan teori sindrom kardiorenal tipe 4 dimana pada PGK terjadi komplikasi hipertensi, aktivasi sistem RAA dan hipervolemia yang jika berlangsung lama dapat berlanjut menjadi kelainan jantung dengan manifestasi tersering berupa hipertropi ventrikel kiri. ${ }^{7,8}$ Disfungsi diastolik juga ditemukan pada 15 dari 25 (60\%) subjek dengan gagal jantung dan 7 dari 25 (28\%) dari subjek tanpa gagal jantung. Hal ini sesuai dengan teori bahwa pada kondisi PGK terjadi hipertrofi ventrikel kiri yang disertai dengan kekakuan dinding ventrikel sehingga menyebabkan gangguan fase pengisian ventrikel (gangguan fase diastolik)., ${ }^{9,10}$

Pada penelitian ini, didapatkan rerata kadar NT-proBNP pada sampel dengan gagal jantung sebesar [23.082 pg/mL (22.413)] dan pada subjek tanpa gagal jantung sebesar $[815 \mathrm{pg} / \mathrm{mL}$ (651)]. Pada gagal jantung kronik tanpa PGK, nilai ambang NT-proBNP untuk mendiagnosis gagal jantung adalah $125 \mathrm{pg} / \mathrm{mL}$. Sedangkan pada gagal jantung akut, nilai ambangnya menjadi 300 pg/ mL. ${ }^{6}$ Pada kondisi PGK, terjadi peningkatan kadar NT-ProBNP walaupun tanpa disertai gagal jantung. Sampai saat ini, belum terdapat nilai acuan yang diterima secara internasional sebagai nilai ambang NT-proBNP pada kondisi PGK. Akan tetapi, beberapa ahli mencantumkan nilai ambang $900 \mathrm{pg} / \mathrm{mL}$ untuk eGFR $>60 \mathrm{ml} / \mathrm{menit} / 1,73 \mathrm{~m}^{2}$ dan $1.200 \mathrm{pg} / \mathrm{mL}$ untuk eGFR $<60 \mathrm{ml} / \mathrm{menit} / 1,73 \mathrm{~m}^{2}{ }^{1}$. Hal ini sesuai dengan penelitian ini, dimana rerata kadar NT-proBNP pada pasien PGK tanpa gagal jantung mengalami meningkatkan $[815 \mathrm{pg} / \mathrm{mL}$ (651)].
Penelitian lain oleh David $\mathrm{dkk}^{12}$ tentang nilai diagnosis NT-proBNP untuk membantu penegakkan diagnosis gagal jantung pada sampel dengan PGK yang telah mengalami dialisis menunjukkan bahwa rerata NT-proBNP pada 47 sampel tanpa gangguan fungsi ventrikel kiri sebesar [2.762 pg/ $\mathrm{mL}$ (625)]. Nilai ini lebih tinggi dibandingkan dengan rerata kadar NT-proBNP pada sampel tanpa gagal jantung pada penelitian ini yaitu sebesar $[815 \mathrm{pg} / \mathrm{mL}$ (651)]. Penelitian yang dilakukan oleh Takase $\mathrm{dkk}^{5}$ juga menunjukkan peningkatan rerata NT-proBNP pada sampel PGK predialisis dengan gagal jantung sebesar $[3.126 \mathrm{pg} / \mathrm{mL}(5,4)]$. Data ini menunjukan kadar NT-proBNP yang lebih rendah dibandingkan penelitian ini $[23.082 \mathrm{pg} / \mathrm{mL}$ $(4.482,64)]$. Meskipun demikian, hasil kedua penelitian ini memperkuat teori bahwa terjadi peningkata kadar NT-proBNP pada pasien dengan PGK baik dengan atau tanpa gagal jantung.

Pada penelitian ini, didapatkan kadar NT-proBNP pada sampel PGK dengan gagal jantung mengalami peningkatan yang lebih signifikan dibandingkan sampel PGK tanpa gagal jantung $(\mathrm{p}<0,001)$. Hasil ini sesuai dengan penelitian yang dilakukan oleh David $\mathrm{dkk}^{12}$ yang menunjukkan rerata NT-proBNP pada PGK dengan gagal jantung lebih tinggi secara signifikan $(p<0,0001)$ daripada PGK tanpa gagal jantung. Hal ini terjadi akibat penurunan ekskresi NT-proBNP oleh ginjal. Kerusakan ginjal yang terjadi, baik dalam keadaan akut maupun kronis, dapat menyebabkan gangguan ekskresi NT-proBNP yang akan berakibat pada kenaikan kadar NT-proBNP dalam serum. ${ }^{1}$ Beberapa studi lain seperti studi yang dilakukan oleh Mishra dkk ${ }^{12}$ telah membuktikan adanya peningkatan kadar NT-proBNP pada pasien dengan penurunan eGFR sehingga interpretasi kadar NT-proBNP pada pasien PGK dalam mendiagnosis gagal jantung memerlukan penyesuaian. Penelitian lain yang dilakukan oleh Wiley $\mathrm{dkk}^{13}$ dengan total sampel 1.739 pasien PGK baik dengan atau tanpa gagal jantung, menunjukkan hasil serupa, yaitu peningkatan nilai NT-proBNP yang berbanding terbalik dengan penurunan eGFR. Dalam penelitian tersebut, semakin berat derajat gagal jantung yang ditunjukkan oleh kelas fungsional NYHA, semakin tinggi pula nilai median NT-proBNP. Hal ini memperkuat hasil penelitian ini bahwa kadar NT-proBNP mengalami peningkatan pada pasien dengan PGK dan nilainya semakin meningkat seiring dengan derajat keparahan gagal jantung.

\section{SIMPULAN}

Pasien PGK di Instalasi Rawat Jalan Poliklinik Ginjal dan Hipertensi RS dr. Soetomo, Surabaya memiliki penyebaran jumlah laki-laki yang lebih banyak 
pada wanita dengan rentang usia 33 tahun hingga 60 tahun dan rerata usia 49 tahun. Rerata eGFR pada pasien PGK yang menjadi sampel penelitian sebesar $\left[25.4 \mathrm{ml} / \mathrm{menit} / 1,73 \mathrm{~m}^{2}\right.$ (11.1)] dan rerata kadar NT-proBNP baik pada pasien dengan atau tanpa gagal jantung sebesar [11.949 pg/mL (19.306,56)] dimana sebanyak $48 \%$ sampel memiliki kadar NT-proBNP $<900$ pg/mL, 6\% sampel dengan kadar NT-proBNP 900-1.200 pg/mL dan 46\% sampel memiliki kadar NT-proBNP $>1.200 \mathrm{pg} / \mathrm{mL}$. Didapatkan rerata kadar NT-proBNP pada pasien PGK dengan gagal jantung sebesar [23.082 pg/mL (22.413)] dan pada pasien PGK tanpa gagal jantung sebesar $[815 \mathrm{pg} /$ $\mathrm{mL}$ (651)]. Didapatkan peningkatan signifikan kadar NT-proBNP pada pasien PGK dengan gagal jantung dibandingkan dengan pasien PGK tanpa gagal jantung $(\mathrm{p}<0,001)$. Sehingga dapat disimpulkan bahwa pasien PGK dengan gagal jantung memiliki kadar NT-proBNP yang lebih tinggi dibandingkan pasien PGK tanpa gagal jantung.

\section{DAFTAR PUSTAKA}

1. Spanaus K, Eckardstein A. Natriuretic Peptides In Cardiac And Renal Failure. Pippete Magz. 2007;P6-10.

2. Srisawasdi P, Vanavanan S, Charoenpanichkit C, Kroll. The Effect of Renal Dysfunction on BNP, NT-proBNP, and Their Ratio. Am J Clin Pathol. 2010:133:14-23.

3. Anwarudin S, Lloyd-Jones M, Boggish A, Chen A, Krauser D, Tung R, Chae C, Januzzi J. Renal Function, CHF, And Amino Terminal BNP Measurement. J Am Coll Cardiol. 2006:47(1): P91-97.

4. Park M, Vittinghof E, Shlipale M, Misra R, Whooley M, Bansal N. Association of N-Terminal Pro-B-Type Natriuretic Peptide with Kidney Function Decline in Persons Without Clinical Heart Failure in The Heart and Soul Study. Am Heart J. 2014:168: 931-939
5. Takase H, Dohi Y. Kidney function crucially affects B-type natriuretic peptide (BNP), N-terminal proBNP and their relationship. Eur J Clin Invest. 2014;44(3):303-8.

6. European Society of Cardiology (ESC). Heart Failure Guidelines. 2016. Diunduh dari : www.escardio.org/Guidelines/Clinical-Practice-Guidelines/ Acute-and-Chronic-Heart-Failure.

7. Lullo L, Gorini A, Russo D, Santoboni A, Ronco C. Left Ventricular Hyperthrophy In CKD Patients: From Pathophysiology To Treatment. Cardiorenal Med. 2015:5: P254-266

8. Taddei S, Nami R, Bruno R, Quatrini H, Nuti R. Hypertension, Left Ventricular Hyperthrophy And Chronic Kidney Disease. Heart Fail Rev. 2011:16: P615-620.

9. Cho Y. Diastolic Dysfunction And CKD. Korean J Intern Med. 2012:28: P22-26

10. Tzatzaki E, Spartalis M, Kamperialis V, Spartalis E, Giannakulais G, Karvounis H, 2017. Diastolic Dysfunction In ESRD Patients. Hell J Nucl Med. 2017;8: P96-102.

11. David S, Kumpers P, Seidler V, Biertz F, Haller H, Fliser D. Diagnostic Value of NT-proBNP for Left Ventricular Dysfunction in Patients with Chronic Kidney Disease Stage 5 on Haemodialysis. Nephrol Dial Transplant. 2008. 23: $1370-1377$

12. Mishra R, Li Y, Ricardo A, Yang W, Keane M, Cuevas M, Et al. Association Of NT Pro-BNP With Left Ventricular Structure And Function In CKD Am J Cardiol. 2013:111(3): P432-438

13. Wiley C, Switzer S, Berg R, Glurich I, Dart R. Association Of BNP Levels With Egfr And Congestive Heart Failure. J Clin Med Res. 2010:8(1): P7-12.

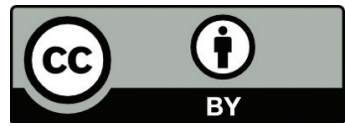

This work is licensed under a Creative Commons Attribution 